\title{
Nie-obywatele. Żydzi jako punkt pikowania polskiej tożsamości
}

\section{Non-citizens. Jews as the quilting point of Polish identity}

\author{
||l Romana Kolarzowa
}

\begin{abstract}
The author points anti-Semitism in Poland as a constant and continuos trait that should not be divided into „anti-Judaism” and „anti-Semitism”. Using the triangulation method, the author indicates the embedding of all European anti-Semitism in the traditional theological narrative and conditioned social solutions, and the reasons for this continuity in Poland. These includes specifics of social structure and particular goals for which the dominant social stratas instrumentalised that discourse. The discourse was supposed to be an inclusive vehicle for subordinated social factions into the nation. Hence significant role of the clergy in that narrative - the only group able to effectively form the collective identity of subordinated and create „anti-modernist” quality of Polish anti-Semitism.
\end{abstract}

Key words: The Jewish Question, national identity, collective identity, alienation

Streszczenie: Autorka twierdzi, że antysemityzm w Polsce ma charakter ciągły i nie można tego zjawiska rozdzielać na „antyjudaizm” i „antysemityzm”. Stosując metodę triangulacyjną, wskazuje osadzenie całego europejskiego antysemityzmu w tradycyjnej narracji teologicznej oraz warunkowanych nią rozwiązaniach społecznych, i przyczyny, warunkujące tę ciągłość w Polsce. Zalicza do nich specyfikę struktury społecznej oraz cele, dla których środowiska dominujące instrumentalizowały dyskurs antysemicki. Dyskurs ten miał być czynnikiem inkluzywnym warstwy podporządkowane do narodu. Stąd znacząca rola duchowieństwa w tej narracji - była to jedyna grupa zdolna skutecznie formować tożsamość zbiorową warstw podporządkowanych i nadawać „antymodernistyczny” charakter polskiemu antysemityzmowi.

Słowa kluczowe: kwestia żydowska (Judenfrage), budzenie świadomości narodowej, konstruowanie tożsamości zbiorowej, obcość

W polskim dyskursie, dotyczącym nie tylko problematyki Zagłady, ale i szerzej - postrzegania Żydów i ich społecznego pozycjonowania - zaczyna coraz częściej pojawiać się świadomość, że - długo absorbująca jako problem (przynajmniej w domniemaniu) realny, na co wskazuje często powracająca 


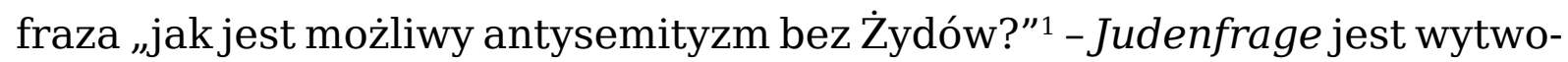
rem kultury zachodniej i ma znacznie mniejszy związek z obecnością społeczności żydowskiej niż z ideologicznym obrazem Żydów, jaki tworzyła kultura dominująca. Praktykowane w tym dyskursie skrupulatne rozróżnianie antyjudaizmu i antysemityzmu przydaje się o tyle, że pozwala na coś wręcz przeciwnego, niż przedstawia się w uzasadnieniach dla tej praktyki (Cała 2012, 17-20), z których żadne nie wydaje się przekonujące: pozwala zobaczyć stabilność wzorca Żyda - wroga odwiecznego ${ }^{2}$, pozbawionego cech ludzkich i wyposażonego we właściwości demoniczne (Trachtenberg 1997, 22-38). Wiedziała to i Hannah Arendt (Arendt 1987), a jednak wiedząc, że „antysemityzm to rzecz nowa z nazwy, ale nie z argumentacji”, starała się wbrew tej wiedzy dowodzić, że jednak jest czymś nowym. Koncepcja Arendt, która zresztą niemal natychmiast wywołała krytykę (najpierw przeprowadził ją Fadiey Lovsky (1955), a dekadę później Edward H. Flannery (1965)), jest nadal wyraźnie obecna w polskim dyskursie antropologicznym i historycznym, dotyczącym problematyki żydowskiej. Klasyczną już formą tego przywiązania są wątpliwości Aliny Całej wobec Gavina Langmuira - że w jego ujęciu antyjudaizm jest kategorią zbyt szeroką (Cała 2012, 81-82); i same sprawiają wrażenie, że kontrowersja dotyczy czegoś całkiem innego, niż dokładność naukowej terminologii. I że sama kontrowersja bynajmniej nie jest zakorzeniona $\mathrm{w}$ metodologii nauk społecznych i humanistycznych. Przywiązanie to daje znać o sobie całkiem aktualnie, nawet tam, gdzie najmniej można by się go spodziewać. „Trzeba się zmierzyć ze źródłami polskiego antysemityzmu, porozmawiać o jego rodzajach - czym był antysemityzm religijny, rasistowski, ekonomiczny czy antyjudaizm" (Leociak 2018, 22-24). Zapoznaje się w tej skrupulatności terminologicznej istotne w moim przekonaniu trzy problemy: a) długie trwanie wzorców kulturowych; b) specyfikę społeczną ziem polskich w drugiej połowie XIX i w ciągu czterech dekad XX wieku; c) wynikające z niej problemy, związane z konstruowaniem nowożytnej tożsamości narodowej.

„Naukowość” czy - szerzej - racjonalność nowożytnego antysemityzmu nie jest czymś radykalnie różnym od racjonalności zawartej w historycznych przekazach. Legendy o krwi mają przecież obszerną i solidną podbudowę teologiczną; a również podlegały bardzo skrupulatnej „medykalizacji”, na miarę ówczesnej wiedzy. Tak samo zresztą, jak czarostwo - tych zjawisk nie można odsyłać do „ludowych przesądów”, bo to jednak była część wiedzy uczonej. Tak samo, jak dowodzenie nie-ludzkiej „natury” Żydów. Anachronizmem jest wyobrażanie sobie, że w XIII czy [lub, albo] też w XVII wieku strach przed „zadaniem choroby” bądź sprowadzeniem nieszczęścia przez dokonanie profanacji był mniejszy, niż w XIX wieku przed

\footnotetext{
$1 \quad$ Przytomnie i zwięźle przedstawił „problem żydowski” Henryk Grynberg: „to nie Żydzi byli „jednym z najbardziej destrukcyjnych elementów” w Polsce, lecz antysemici. Byli i są” (Grynberg 2003,14). Jest to odwołanie do tytułu pracy Aliny Całej.

Korzystałam z wydania francuskiego, tłumaczenie polskie - Arendt 1982.
} 
„miazmatami” [bądź] czy „zrujnowaniem”4. (Podobnie jest anachronizmem odmawianie temu wcześniejszemu strachowi charakteru racjonalnego). Racjonalność tego strachu potwierdzały przecież autorytety. Mimo oczywistości tego spostrzeżenia nie tracą mocy konkluzje w rodzaju: „antysemityzm łatwo [w drugiej połowie XIX wieku] ogarniał umysły wielu. Dzięki zawartej w nim pseudonaukowej teorii rasistowskiej stał się możliwy do zaakceptowania dla inteligencji” (Cała 1987, 14). Dla ścisłości należy przypomnieć, że warstwy wykształcone i kulturotwórcze miały w każdym stuleciu dość autorytetów, czyniących antysemickie imaginarium „możliwym do zaakceptowania”. A w drugiej połowie XIX wieku inteligencji w zupełności wystarczyliby Wolter i Hegel.

$\mathrm{Na}$ ziemiach polskich w drugiej połowie XIX wieku problemem nie było jednak, co może zaakceptować inteligencja, ale w jakiej formie można przekazać warstwom podporządkowanym to, co zostanie uznane za właściwe i użyteczne do przekazania w celu symbolicznej inkluzji tych warstw do narodu. Ponieważ warstwy te mentalnie nie tylko znajdowały się daleko od nowoczesności, ale w zdecydowanej większości nie dysponowały żadnymi narzędziami, umożliwiającymi bezpośredni (a tym bardziej krytyczny) z nią kontakt, należało oferowane im „nowoczesne” imaginarium przekazać tak, aby stanowiło kontynuację tego, co znane i utrwalone. Jakkolwiek „nowocześni” chcieliby być antysemici z ubiegłego stulecia, chcąc osiągnąć zakładane cele, musieli swój przekaz dostosować do poziomu percepcyjnego audytorium i do jego zasobów możliwych skojarzeń. Przeprowadzenie takiej implementacji za pomocą ducha narodowego, reprezentowanego przez twórczość Fryderyka Chopina czy koncepcje historiozoficzne Hoene-Wrońskiego, byłoby raczej kontrproduktywne.

Sposób konstruowania tego imaginarium interesująco zanalizował Konrad Matyjaszek (Matyjaszek, 92-99; 130-133). Wskazał na kilka punktów pikowania, nieodzownych w polskim dyskursie nie tylko „o Żydach”, ale i o samych sobie (goście, gospodarze, opieka, wdzięczność/niewdzięczność), wskazując, że wyidealizowany (bo inny nie jest potrzebny) wizerunek własny byłby niekompletny i nie dość „pański” bez Żydów. Poniekąd analogicznie, jak sama „pańskość” klasowego hegemona byłaby jakoś ułomna, gdyby hegemon - jadając swój syr i truskawki - jadał go z dala od spojrzenia chama swego, odejmując sobie tę część rozkoszowania się, jaką czerpać mógł z tego bycia widzianym i z jadania przeciwko chamowi swemu (Leder 2014, 105-107). W tej scenie Gombrowicz jest intuicyjnym lacanistą przed Lacanem.

Struktura tego dyskursu nieodmiennie sytuuje jego „przedmiot” na pozycji podporządkowanej i pasywnej. Stan rzeczy, ustalony w wiekach średnich - że o Żydach się mówi, chociaż Żydzi głosu nie mają - wspólny dla

${ }^{4}$ Znakomicie te związki przedstawił K. Matyjaszek w dysertacji doktorskiej napisanej pod kierunkiem I. Grudzińskiej-Gross, Produkcja przestrzeni pożydowskiej w miastach dawnej i współczesnej Polski. Praca niepublikowana, w bibliotece Instytutu Slawistyki PAN. Na rolę Stanisława Staszica w transformacji antyżydowskiego toposu teologicznego zob. również (Leociak 2018, 28-29). 
przestrzeni kultury europejskiej, strefowo ulegał modyfikacji przez przynajmniej formalne uznawanie Żydów za współobywateli. Jednak ta strefowość nie tylko nie zahaczyła o ziemie polskie - tu ten stan rzeczy uległ wzmocnieniu, a leitmotivem tego wzmocnienia stało się wykazywanie zasadności nie-obywatelskiej pozycji Żydów i konieczności jej utrzymywania. Przez rozmaite formy dyskursu perswazyjnego, wśród których wyróżniłabym perswazje o charakterze religijnym lub też wykorzystujące schematy religijne, na dobre utrwaliła się w świadomości potocznej pozycja podmiotowa Żyda jako „gościa” - pozbawionego praw innych, niż arbitralnie udzielone przez „gospodarzy”. Im bliżej współczesności, tym chętniej status „gościa” ograniczany był do roli sublokatora. Wszelako w tym przypadku bez zagłębiania się w szczegóły, takie jak intratność procederu wynajmu - skądinąd szeroko omawianego przy sposobności „czysto ekonomicznej”, takiej jak np. biznes czynszówkowy, dla którego racją istnienia i gwarancją opłacalności było istnienie populacji, pozbawionej praw właścicielskich do nieruchomości.

Powód, dla którego wyróżniam perswazję religijną i parareligijną, wiąże się nie tylko ze specyfiką demograficzną ziem polskich, ale i z celem intensyfikacji dyskursu antysemickiego w tym czasie. Cel ten związany był ściśle z operacją „budzenia świadomości narodowej”, czyli z rekonstrukcją tradycyjnej kategorii „narodu” i z możliwie szybkim zatarciem jego cechy pryncypialnej, to znaczy ekskluzywizmu klasowego. Było to szczególnie pilne na ziemiach należących do monarchii austrowęgierskiej, gdzie pod koniec XIX wieku żywa była pamięć chłopskiej rewolty z 1846 roku i następujących po niej co najmniej dwóch dekadach wrogości klas podporządkowanych wobec klasowego hegemona ${ }^{5}$. Tradycyjnie hegemon ten swoją pozycję legitymizował różnicą jakościową: krew sarmacka daje prawo do pełnej władzy nad tymi, którzy są jej pozbawieni. Przejście z takiej tradycji do "zjednoczenia narodowego", rozumianego w duchu wspólnoty etnicznej (plemienności, jednej krwi), z równoczesnym zachowaniem pozycji uprzywilejowanej oraz obyczajowej odrębności, było zadaniem niewykonalnym bez ustanowienia jakiegoś zapośredniczenia.

Dla osiągnięcia tego celu niezmiernie istotne było wyeksponowanie tego, co może być łącznikiem pomiędzy uprzywilejowanymi i podporządkowanymi, odwrócenie uwagi od znaczącego zróżnicowania obyczajowego oraz przekierowanie wrogości klasowej na „bezpieczny obiekt”. Nadanie religijnych lub parareligijnych ram nowej narracji „świadomości narodowej" pozwalała na realizację i tego celu (Tokarska-Bakir 2015). To dlatego zaczęto eksponować kwestię wyznaniową jako czynnik integrujący,

\footnotetext{
Pamięć tej rewolty przetrwała w niektórych regionach Małopolski aż do początku XXI w. W jednym z projektów, dotyczących poznawania lokalnej historii, pojawiały się opowieści, w których Jakub Szela był bohaterem pozytywnym, wspomaganym przez siły nadprzyrodzone (anioły sprawiły, że w jedną noc dotarł spod Tarnowa do Wiednia, aby ostrzec cesarza, że panowie hrabiowie zjechali się radzić, jak cesarza zgładzić); i zarazem był „przodkiem w porządku ducha” Wincentego Witosa, którego opowieści te przedstawiały jako odpowiedź z nieba na chłopskie modlitwy. Projekt Stąd jesteśmy, Olimpów, gm. Iwierzyce, pow. ropczycko-sędziszowki, woj. podkarpackie, $2006 \mathrm{r}$.
} 
ustanawiając - dość dowolnie ${ }^{6}$ - paradygmat Polaka katolika. Taka differentia specifica, poza tym, że ahistoryczna, miała charakter instrumentalny, obliczony na możność przyswojenia przez warstwy niewykształcone; realnie nie była żadnym narzędziem odróżnialności nie tylko w stosunku do etnii - z perspektywy tych, do których ten przekaz był adresowany - egzotycznych (Włosi, Irlandczycy, Francuzi), ale i w stosunku do sąsiadów, poddanych Arcykatolickiego Cesarstwa. Dla tego też celu nadzwyczaj istotne było odwrócenie uwagi jednakowo od trybu życia hegemona i warunków bytowych podporządkowanych; należało zintensyfikować prace na rzecz obsadzenia w roli „klasy próżniaczej”, a zarazem nieusuwalnych nosicieli miazmatów - brudu, chorób, patologicznych zachowań ${ }^{7}$ - obiektu bezpiecznego, bo tradycyjnie przedstawianego jako "ciało obce” i "egzotyczne”, choć dla klas podporządkowanych tiurniury, fortepian i herbata były równie egzotyczne, jak tefilim, szofar i czulent.

Nie można pomijać nurtów emancypacyjnych, rozwijających się w XIX wieku i adresowanych do warstw ludowych - tu zwłaszcza ruchy socjalistyczne postrzegane były jako istotne zagrożenie. Gra toczyła się więc długofalowo - o takie uwiedzenie woli warstw ludowych, które przyjmując sztafaż modernizacji i emancypacji, pozwoliłoby na utrzymanie jej w stanie podporządkowania. Mechanizm uwiedzenia woli oraz transformowania jej w wole protagoniczna przeanalizował Adam Kubiak. Wiąże on tę transformację z „odzyskaniem tożsamości” lub też „nawróceniem” o bardzo charakterystycznej dynamice:

Człowiek 'samoistnie nawrócony' rekapituluje swoje nawrócenie najczęściej jako „przejrzenie na oczy” lub „zrozumienie” (...). Paradoksem „nawróceń” woli protagonicznej jest niezbędność autorytetu, [podkr. RK] którym może być ktokolwiek i cokolwiek, byle było jednocześnie dostatecznie silne, „idealne” (...) i nieokreślone (Kubiak 2008, 40).

Jednym z najbardziej interesujących przykładów, w jaki sposób konstruowanie zbiorowej tożsamości, czyli „budzenie świadomości narodowej" w warstwach plebejskich, ogniskowano na modernizacji i eskalacji toposów antysemickich, jest postrzeganie przez współczesnych działalności galicyjskiego animatora ruchu ludowego, Stanisława Stojałowskiego. To, co najbardziej tu znaczące, to okoliczność, że administracja monarchii austrowęgierskiej szczebla centralnego znakomicie zdawała sobie sprawę z charakteru tej działalności i jej politycznych konsekwencji, jednoznacznie oskarżała Stojałowskiego o inspirację pogromów i domagała się od nuncjusza w Wiedniu sankcji kościelnych. Domagał się tego osobiście minister spraw zagranicznych, hrabia Agenor Gołuchowski (Kertzer 2005, 231-236).

\footnotetext{
$6 \quad$ Klasa dominująca miała przez Konfederację Warszawską zagwarantowaną swobodę wyznaniową - wewnątrz niej tożsamość nie była związana z wyznaniem.

Nie zawsze te wysiłki były efektywne - „psuła” je niekiedy literatura (Prus, Reymont, Żeromski) oraz - nie zawsze intencjonalnie - prasa. Jeszcze w latach 30. XX wieku prasa „groszowa” chętnie eksponowała tytuły w rodzaju „Wieś wylęgarnią zbrodni”.
} 
Nuncjusz Antonio Agliardi widział jednak w tej działalności inne, znaczniejsze zagrożenie. Stojałowski

Agituje wśród chłopów, którzy go wielbią i wspierają finansowo. Podburza wieś, szerzy nienawiść do bogaczy i biskupów, chce zniszczyć ich autorytet. (...) A wszystko to czyni, twierdząc (z wielką hipokryzją i na szkodę ludności wiejskiej), że upowszechnia nauki Ojca Świętego w dziedzinie socjalizmu (Kertzer 2005, 232).

Ten przypadek pozwala dostrzec mechanizm transformacji starego, legitymizowanego teologicznie toposu antyżydowskiego w narzędzie konstruowania, rekonstrukcji i modernizacji „polityki tożsamościowej” (Kubiak 2015, 139-162) ${ }^{8}$. Bez zaangażowania w tę transformację znacznej części duchowieństwa, czyli środowiska najlepiej zorientowanego w tradycyjnym imaginarium antyżydowskim, a zarazem jedynego, które wobec warstw podporządkowanych znajdowało się zarazem blisko i mogło posługiwać się autorytetem z porządku wyższego, niż władza świecka, odnowienie wizerunku Żyda - wroga odwiecznego i przystosowanie go do realiów współczesnych byłoby trudniejsze. Trudność największa zawarta była w modernizacji nieiluzorycznej - tej, która opisywała swój cel jako emancypację mniejszości podporządkowanych i uznanie ich podmiotowości obywatelskiej, a której symbolem stał się Kodeks Napoleoński i inspirowane nim ustawodawstwa krajowe. Dlatego należało zawczasu częściowo zdyskredytować ten typ modernizacji, przedstawiając go jako twór „żydowsko-masoński”.

Znaczącą rolę w tym procesie „unarodowienia” mają pogromy. Joanna Tokarska-Bakir, odwołując się do koncepcji Roberty Senechal de la Roche, wskazuje na rolę przemocy kolektywnej w konsolidacji grupy i w uznaniu, że posiada ona moc sprawczą „przywracania porządku”. Przyjęcie założenia, że pogrom jest aktem kontroli społecznej, zwróconej przeciwko temu, co dana grupa uznaje za najbardziej odstręczającą dewiację (Tokarska-Bakir 2018, 246-247), pozwala zrozumieć znaczenie uczestnictwa w nim dla grup podporządkowanych i całkowicie pozbawionych sprawczości. I jakikolwiek byłby „rzeczowy” pretekst dla pogromu, jego faktycznym uzasadnieniem jest postrzeganie tych, w których jest wymierzony jako istniejących w sposób dewiacyjny.

Imaginarium, oparte na dobrze znanych i zbadanych wątkach wampirycznej natury Żydów, żydowskiej perfidii, polskiej gościnności wobec Żydów, służyło bezpośrednio trzem celom:

a. stygmatyzacji, opresji i podporządkowania/utrzymania statusu podporządkowania tak naznaczonej mniejszości;

b. wykreowania zbiorowego „Ja idealnego" i afirmatywnej tożsamości;

c. użycie stygmatyzowanej mniejszości do inkluzji podporządkowanej większości w strukturę zbiorowego „Ja idealnego”. również współcześnie, wnikliwie przedstawił Adam Kubiak w książce Rzeczy mniejsze. Dysformia i fiasko: semi-peryferyjne formy kultury (Kubiak 2015). 
Cały ten projekt polityczny, zainicjowany w XVIII wieku, a nazwany projektem modernizacyjnym, miał swój punkt pikowania w całkowicie nienowoczesnym toposie wykluczania Żydów nie tylko z konkretnej społeczności, ale wręcz ze wspólnoty ludzkiej - jego miejsce było płynne, oscylujące między światem demonów a światem zwierząt (Trachtenberg 1997, 21-55). Nawet implementowanie w „modernizacyjne” imaginarium Żyda wątków higienistycznych (miazmaty) mają charakter transkrypcji tradycyjnego wyobrażenia „żydowskiej zarazy” (Matyjaszek, 152-154; 223231). Przekształcenia stygmatyzacji teologicznej i parateologicznej Żydów w stygmatyzację „unaukowioną”, gdzie koneksje diaboliczne zostają zastąpione racjami higienicznymi stwarzają iluzję nowoczesności. Tracąc demoniczność, Żydzi nie zyskują człowieczeństwa - pozostają częścią przyrody, czyli tego, z czym identyfikuje się zagrożenie dla człowieka: nosicielami miazmatów, należącymi do tego samego porządku, co świnie czy robactwo. Być może ich status zwierzęcy ulega sublimacji do sfery symbolicznej i nie dawano by już wiary, że Żydówka może urodzić prosięta (Trachtenberg 1997, 55). Ale jedna $\mathrm{z}$ fundamentalnych trosk, odżydzanie - na wzór dezynsekcji i deratyzacji - miast, kultury, szkolnictwa, akademii itd. bynajmniej nie wyraża się w projektowaniu operacji symbolicznych. Ten ekskluzywny projekt wprost został zafiksowany na koncepcji Żyda nie-obywatela, która antycypowała bardzo już współczesną kategorię Fremdkörper. I wraz z fantazmatem Polski - Niewinnej Ofiary - została przekształcona w mit założycielski Polski współczesnej (Janion 2007, 283-285, Janicka 2013). Ma rację Paweł Brykczyński, wskazując:

W Polsce, inaczej niż we Włoszech, jadowity polityczny antysemityzm poprzedzał poparcie dla polityki autorytarnej, nie mówiąc już o totalitarnej. (...) Kluczowa różnica względem Włoch polega na tym, że w Polsce, podobnie jak w Rumunii czy na Węgrzech, „kryzys” narodu i nadchodzący "nowy porządek” obracały się niemal wyłącznie wokół jednego problemu: kwestii żydowskiej [podkr. RK] (Brykczyński 2017, 34-35).

Dlatego zresztą taki mit założycielski [skonstruowany i utrwalony mit założycielski „jednolitości narodu polskiego"] skutkował mordem założycielskim: Gabriel Narutowicz został zamordowany dlatego, że był osobą, na którą ośmielili się głosować nie-obywatele.

Romantyczna wersja tego mitu pozornie oferowała mniejszości żydowskiej inkluzję. Jednak ta oferta była zakorzeniona w opresyjnym fantazmacie dobrego Żyda - tym samym, który ujawnia się wprost w haśle należącym do ideologii pogromowej: „dobry Żyd to martwy Żyd”. Oferta inkluzji nie jest kierowana do żywych; dotyczy tych nielicznych, którzy umarli we właściwy sposób i pod właściwym znakiem - aczkolwiek i dla nich, jak wskazuje pochówek Berka Joselewicza, najwłaściwszym ostatnim miejscem okazuje się miejsce wśród natury, wedle legendy wybrane przez w pełni do tej natury przynależne woły. Bo to im, a nie towarzyszom broni, przypadł honor zadbania o zwłoki pułkownika (Matyjaszek, 115-117). Inkluzja, nawet na 
takich warunkach, sprowadzona do uznania polskości post mortem jest zresztą nadal formą zawłaszczenia - podmiot tej inkluzji, w chwili jej dokonywania, już nie istnieje. Inkluzja jako „nagroda pośmiertna” jest gestem pustym wobec unicestwionego podmiotu, a znaczącym tylko dla tych, którzy go dokonują, utwierdzając nim swoje idealne ego. Jakkolwiek iluzoryczny, ten wariant mitu został zanegowany w obrębie samego romantyzmu: tworząc w Nie-Boskiej komedii postać Pankracego, Zygmunt Krasiński odnowił wątek „marrański” - konwersja nie ma właściwości inkluzywnych, bo „złowroga żydowska natura” silniejsza jest od sakramentu. Osobliwa to u katolika konstatacja teologiczna, ale od drugiej połowy XIX wieku będzie ona zyskiwać na znaczeniu w dyskursie „żydoznawczym” (jak określali go sami animatorzy), zwłaszcza w tych jego odmianach, w których ton będą nadawać uczeni duchowni pokroju księży Wincentego Lutosławskiego, Józefa Kruszyńskiego, Józefa Pastuszki czy Stanisława Trzeciaka.

W micie tym punktem ogniskującym zarówno wizje przyszłości, jak i dyskurs tożsamościowy jest produkcja różnicy: kto jest i kto może być Polakiem. Szczegółową analizę zabiegów przemieszczania pojęć i ich sensów, mających skonstruować naród tak, aby nie naruszyć tradycyjnej struktury klasowej, przedstawił Wiktor Marzec (Marzec 2016, 297-325). Rzecz znamienna, poświęcając wiele uwagi nacjonalistycznym programom przemienienia ludu w naród (oraz hermeneutycznym meandrom, z tymi kategoriami związanymi), Marzec całkowicie „wycina” z tej analizy problem obywatelskości Żydów, mimo że problem ten w analizowanych tekstach jest jednym $\mathrm{z}$ kluczowych. Zwłaszcza dla zakreślenia i umocnienia granic narodu. Nie bez powodu jedną z najbardziej poczytnych publikacji z początku XX wieku była wydana w 1904 roku publikacja Teodora Jeske-Choińskiego Neofici polscy: materyały historyczne (Jeske-Choiński 1904). Ten swoisty odpowiednik Liber chamorum Waleriana Nekanda Trepki pozwala na uznanie, że żadna, nawet najbardziej radykalna, bo polegająca na dekulturacji, forma integracji nie była ani zadowalająca, ani pożądana. Co więcej, przez prowadzoną śladem Krasińskiego stygmatyzację konwertytów destrukcji poddane zostają dwa spośród fundamentalnych wierzeń chrześcijańskich, związanych z właściwościami chrztu oraz powszechnością wspólnoty ochrzczonych; to jednak zagadnienie, na które nie zwrócono większej uwagi, mimo znaczącego udziału duchowieństwa w rozwijaniu doktryny Żyda jako ciała obcego. Być może w tej obsesji „przechrztów” powraca „wyparta przemoc chrystianizacji jako pewnego typu kolonizacji, a w tym konkretnym przypadku chrystianizacji zachodniej rozumianej zarówno jako kolonizacja ekonomiczna (...), jak i ideologiczna" (Kubiak 2015, 149). Jako znacznie istotniejsza postrzegana była potrzeba opanowania sztuki odróżniania Żyda i rozpoznawania jego „prawdziwej natury”. Pisze Jeske-Choiński:

Od sześciu wieków gnieździ się to plemię pasożytnicze na naszej skórze, ssie nasz pot, naszą krew (...). Dla przeciętnego Polaka był i jest Żyd przede wszystkiem zabawny, śmieszny, komiczny, dowcipny, dobrodusznie chytry (...). Bawiliśmy się 
i bawimy dotąd zabawnymi Moskami, Ickami (...), przedrzeźniamy, śmiejąc się do rozpuku, ich komiczne ruchy, ich koszlawy, odpadkami różnych języków popstrzony szwargot (Jeske-Choiński, 5-6).

Widać tu jednoznacznie nie tylko streszczenie właściwego charakteru "gościny”: „gość” zajmuje de facto (a wbrew kulturowym regułom gościnności) tak niską pozycję, że można bez skrępowania wyśmiewać; za znacznie ważniejsze mam czytelne w tym tekście przekierowania:

a. resentymentu klasy podporządkowanej - nie ma innych poza Żydami „plemion pasożytniczych”, żywiących się „potem i krwią”;

b. obyczaju wyśmiewania przedstawicieli klas podporządkowanych - to, co było przedmiotem dowcipów, rzadko wybrednych ${ }^{9}$, tworzonych przez uprzywilejowanych kosztem podporządkowanych, „należy się” Żydom.

Nieistotne ani to, czy Żydzi tacy są, ani to, czy tak sa potocznie postrzegani - istotne, że tak powinni być postrzegani. Ta rama narracyjna będzie organizować cały XX-wieczny „dyskurs żydoznawczy”, rozpostarty między zgłębianiem „egzotycznej duszy” bądź „psychiki żydowskiej” (resp. semickiej), miazmatologia - czyli tropieniem „rozkładowych pierwiastków żydowskich”, sprowadzającym się jednoznacznie do tropienia pochodzenia etnicznego, niezależnie od afiliacji kulturowych - i komponowaniem przepisów

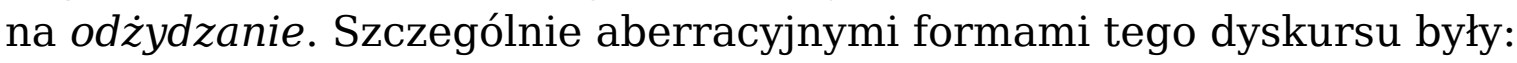

a. operowanie wzajemnie wykluczającymi się zarzutami, np. brakiem zdolności twórczych i niewyczerpaną inwencją w „opanowywaniu świata” czy niezdolnością do „całkowitej asymilacji” i asymilacją tak gruntowną, że uniemożliwiającą identyfikację - przykładem tej aberracyjności może być uznawanie za niedopuszczalne udostępnianie zasobów literatury polskiej czytelnikom żydowskim (Bergmann 2015, 285).

b. depolonizacja wybitnych postaci nauki i kultury, w tym takich, które kulturę polską promowały w świecie (np. Artur Rubinstein, Eli i Paweł Kochańscy czy Grzegorz Fitelberg) (Bergmann 2015, 75-283).

Aby wiedzieć, kim się jest, i aby móc umacniać swoją pozycję, trzeba tropić różnice; aby móc je efektywnie tropić, trzeba ćwiczyć się w umiejętności ich wynajdywania. Dyskurs oparty na produkcji różnicy, trwający już w podczas II wojny światowej, lapidarnie przedstawił Ludwik Hering:

biała, krótkowzroczna blondynka (...) zwierzała się prowadzącemu ją panu: Chwilami zapominam, że to są Żydzi i to jest jednak straszne. (...) Inny pan (...) uzasadniał swoją obojętność dla losu Żydów obcością etnograficzną, etyczną i psychiczną swej środkowoeuropejskiej czy śródziemnomorskiej kultury. - U nas,

\footnotetext{
$9 \quad$ Ten repertuar obejmował np. chłopski sposób mówienia, wrażliwość (Wałku, czemu twoja tak płacze? - A, bom jej rzekł, że ociec pomarli. - Jakże to, pomarł, skoro rano tu był? - No, prowda... Krasula nom padła, alem moji tak zaroz mówić nie chcioł) czy obyczaje. Wiele takich dowcipów powstawało na początku XX wieku, m.in. po premierze Halki Stanisława Moniuszki.
} 
ludzi przesiąkniętych kulturą Zachodu, przeważa nie przewrotny intelekt talmudystów, ale prosta uczuciowość. Stąd właśnie moja obcość i mój brak współczucia (Hering 2011, 82-83).

W tym - literacko zsyntetyzowanym - mętnym wywodzie, będącym ekstraktem z dyskursu „żydoznawczego” jeden element, legitymizujący przynależność do „środkowoeuropejskiej czy śródziemnomorskiej” kultury, jest pewny i niewątpliwy na miarę kartezjańskiego cogito: brak współczucia. Jak bardzo nie był to przypadek indywidualny, wskazuje Sprawozdanie kościelne z Polski za czerwiec i połowę lipca 1941-go roku:

trzeba to uważać za osobliwe zrządzenie Opatrzności Bożej, że Niemcy, obok mnóstwa krzywd, jakie wyrządzili i wyrządzają naszemu krajowi, pod tym jednym względem dali dobry początek, że pokazali możliwość wyzwolenia polskiego społeczeństwa z pod żydowskiej plagi [podkr. RK] (...) Jest to wyraźne zrządzenie Boże, że sami okupanci przyłożyli rękę do rozwiązania tej palącej kwestii (Leociak 2018, 82, 2016).

To jest ostateczna granica wykluczenia, gdy mordowanie nie-obywateli jest czynem wyzwoleńczym, choć dokonywanym przez okupanta. Ale po dotarciu do tej granicy nadal możliwa jest „pusta inkluzja”: gdy pomordowanych zacznie się liczyć do strat narodu polskiego i gdy zacznie się po gospodarsku użytkować mienie pożydowskie.

Hering uchwycił też produkcję różnicy w wymiarze praktycznym i w momencie kulminacyjnym:

zatrzymał Niemiec kobietę. Woła mnie. Każe zdjąć chustkę. Blondyna, niczego nawet. Włosy z jednej strony przysmażone. Dowód? W porządku. Meldunek? Górczewska. Dobrze. Włosy? Mówi, że przy gazie. Spokojna. Egzaminek: Zdrowaś? Owszem. Sakramenty? Jak ta lala. No, to dam ci, siostro, zagadkę: Co trzeba zrobić, jak się odchodzi od spowiedzi? Wie. Tu mnie zatknęło. Niemiec prawie puszcza, daje mi ją do sprawdzenia. Na komisariat. Nie bądź ty dla mnie taka mądra, bo się jeszcze, broń Boże, nie uchowasz. Dzwonię tu, tam i jeszcze - zgadza się, chrzczona przed ślubem. A widzisz, siostro? Czułem, żeś trefna... (Hering 2011, 91).

Tak przedstawiona procedura, w której ujawnia się jedność tropienia i produkowania różnicy, znienacka kieruje uwagę na motyw wszechobecny we wspomnieniach Ocalonych: na pilne uczenie się katolickich modlitw, reguł liturgicznych i bardzo szczegółowych zachowań, związanych ze sferą religijną. I zatrzymuje tę uwagę na tym, co rzadko zostaje dopowiedziane wprost - w przewidywaniu jakich egzaminatorów była ta nauka? Prawie żaden Niemiec nie znał języka polskiego na tyle dobrze, aby ocenić poprawność modlitwy (czy jakiejkolwiek innej wypowiedzi); poza tym nie każdy był katolikiem, więc większość tych modlitw i praktyk była mu tak obca, że ani nie miałby powodu o nie pytać, ani nie miałby kompetencji, aby oceniać poprawność odpowiedzi - gdyby ktoś inny zapytał. Zatem, zważywszy powszechność tego elementu żydowskiej strategii przetrwania, rzeczywiście ktoś inny pytał i oceniał. Ktoś, kto nie tylko potrafił różnicę 
wytropić, ale - w razie potrzeby - wiedziałby, jak i z czego ją wytworzyć. Umacniając w sobie pewność swojego czucia, a przez to i siebie, rozkoszując się jedną z podstawowych mocy oddzielania czystego od nieczystego; a niewykluczone, że aktywne zajęcie pozycji ja decyduję, kto jest Żydem rodziło poczucie dobrze spełnionego obowiązku „wyzwolenia od wewnętrznego okupanta".

W tej produkcji wszystko mogło być materiałem. Umiejętność pikowania tożsamości na odróżnianiu przetrwała Zagładę i przeszła zasadniczo nietknięta w drugą połowę XX wieku. Ujawniła się w powojennych pogromach - którym fundamentalne prace poświęciła Joanna Tokarska-Bakir. Ujawniała się też „subtelniej”, za to codziennie. Wspomina Paulina Chmielnicka:

Żyłam z tym antysemityzmem od kolebki. Nie nazywaj się Pesa, bo cię będą przezywać. Skakanką kręcisz, jak „parszywa żydówa”. Na ulicy łapią cię za włosy i mówią „parszywa żydówa” (Grynberg 2018, 72).

Tak łączy się tradycja z nowoczesnością: żydowskie włosy i żydowska skakanka. Bo wszystko może być albo normalne, albo żydowskie, co precyzyjnie zapamiętała Ala Elczewska:

Pamiętam ze szkoły taką scenę: Majka ucieka, a za nią lecą koledzy z klasy i się drą: żydówa, żydówa! I jeszcze kiedyś Majka dostała od nauczycielki w twarz, bo pisała dziewiątkę po żydowsku.

\section{Jak się pisze dziewiątkę po żydowsku?}

Gdy zaczynasz od ogonka i ciągniesz do góry, odwrotnie niż wszyscy (Grynberg 2018, 130-131).

Mija pół wieku. I w przestrzeni publicznej można znów dyskutować o tym, czy wnuczka Żyda jest Żydówką. Można czytać - bo są dostępne w sieci wywody antropometryczne, w których uczy się, jak rozpoznać Żyda; opowiadać dowcipy, których próbkę podaje Henryk Grynberg (Grynberg 2011, 101). Można też mówić, nieanonimowo, o kilku parchach, a gdy tę wypowiedź zakwalifikuje się do mowy nienawiści, grozić pozwem. I można jeszcze wiele innych rzeczy, ciągle na ten sam temat. Tożsamość, podobno, okrzepła i nic dziwnego, skoro niezależnie od zwrotów ideologicznych (TokarskaBakir, 2008, 612-636) jest umocowana w tych samych punktach. Istotną właściwość tego stabilizatora i gwaranta tożsamości uchwyciła jedna z nie-obywatelek, Renata Skotnicka: - Tylko żeby udawać Polaka, trzeba było mówić na Żydów. - Mówiłaś? - Mówiłam (Bikont 2017, 46). Przezwisko Kryśka antysemitka było dla Krystyny Podbielskiej (okupacyjna tożsamość Skotnickiej) uwiarygodnieniem lepszym niż blond włosy i medalik.

\section{Bibliografia:}

Arendt Hannah, 1982, Żyd jako parias - ukryta tradycja, Kołyszko P. (przeł.), „Literatura na Świecie”, nr 12 (137).

Arendt Hannah, 1993, La tradition cachée - le Juif comme paria, Bourgois, Paris 1987. 
Bergmann Olaf, 2015, Narodowa Demokracja a Żydzi 1918-1929, Poznań.

Bikont Anna, 2017, Sendlerowa. W ukryciu, Wołowiec.

Brykczyński Paweł, 2017, Gotowi na przemoc. Mord, antysemityzm i demokracja w międzywojennej Polsce, Sutowski M. (przeł.), Warszawa.

Cała Alina, 1987, Wizerunek Żyda w polskiej kulturze ludowej, Warszawa.

Cała Alina, 2012, Żyd - wróg odwieczny. Antysemityzm w Polsce i jego źródła, Warszawa.

Flannery Edward H., 1965, The Anguish of the Jews: Twenty-three Centuries of Antisemitism, Macmillan, London.

Grynberg Henryk, 2003, Monolog polsko-żydowski, Wołowiec.

Grynberg Mikołaj, 2018, Księga wyjścia, Wołowiec.

Hering Ludwik, 2011, Ślady, Warszawa.

Hertz Aleksander, 1979, Wyznania starego człowieka, Londyn.

Janicka Elżbieta, 2013, Latający Cyrk im. Kazimierza Wielkiego przedstawia: „Najwęższy dom świata - wydarzenie na skale globu". Rekonstrukcja historyczna w 70. Rocznice Akcji Reinhardt, „Studia Litteraria et Historica”, 2, s. 76-129.

Janion Maria, 2007, Niesamowita Słowiańszczyzna. Fantazmaty literatury, Kraków.

Jeske-Choiński Teodor, 1904, Neofici polscy: materyały historyczne, Warszawa.

Jeske-Choiński Teodor, Poznaj Żyda!, Warszawa-Lwów, b.d.w.

Kertzer Dawid, 2005, Papiė̇e a Żydzi. O roli Watykanu w rozwoju współczesnego antysemityzmu, Nowakowska A. (przeł.), Warszawa.

Kubiak Adam, 2008, Twarz wroga. Próba fenomenologii protagonizmu, Rzeszów.

Kubiak Adam, 2015, Rzeczy mniejsze. Dysformia i fiasko: semi-peryferyjne formy kultury, Rzeszów.

Leder Andrzej, 2014, Prześniona rewolucja. Ćwiczenie z logiki historycznej, Warszawa.

Leociak Jacek, 2016, „Osobliwe zrzadzenie Opatrzności Bożej...”. Polska pamięć Zagłady w perspektywie katolicko - narodowej, „Teksty Drugie”, nr 6, s. 122-152.

Leociak Jacek, 2018, Muzeum trudnych pytań, rozmowa J. Podgórskiej z P. Wiślickim i J. Leociakiem, „Polityka”, nr 16 (3157), s. 22-24.

Leociak Jacek, 2018a, Młyny boże. Zapiski o Kościele i Zagładzie, Wołowiec.

Lovsky Fadiey, 1955, Anti-semitisme et mystere d'Israel, Paris.

Marzec Wiktor, 2016, Rebelia i reakcja, Łódź-Kraków.

Matyjaszek Konrad, niepublikowana praca doktorska Produkcja przestrzeni pożydowskiej w miastach dawnej i współczesnej Polski, Biblioteka Instytutu Slawistyki PAN, promotor: Irena Grudzińska-Gross.

Tokarska-Bakir Joanna, 2008, Legenda o krwi. Antropologia przesadu, Warszawa.

Tokarska-Bakir Joanna, 2018, Pod klątwa. Społeczny portret pogromu kieleckiego, t. 1, Warszawa. 
Tokarska-Bakir Joanna, 2015, The Pogrom As an Act of Social Control Springfield 1908 - Poland 1945-46, A Keynote at the international conference "Pogroms: Collective Anti-Jewish Violence in the Polish Lands in 19th and 20th Centuries", Warsaw, June 10-12, 2015 (online:)

https://www.academia.edu/13070346/The Pogrom As an Act of Social Control_Springfield_1908__Poland_1945-46 (dostęp: 2018.05.01).

Trachtenberg Joshua, 1997, Diabeł i Żydzi. Średniowieczna koncepcja Żyda a współczesny antysemityzm, Stiller R. (przeł.), Gdynia.

\section{O Autorce:}

Romana Kolarzowa - dr hab., zajmuje się antropologią kulturową, ze szczególnym uwzględnieniem problematyki tożsamości oraz doświadczeń traumatycznych. W ciągu ostatnich dwu lat publikowała w „Tekstach Drugich” i „Kwartalniku Filozoficznym”. Pracuje w Instytucie Filozofii Uniwersytetu Rzeszowskiego. 
